\title{
Impact of Educational Program about Iron Chelation Therapy on the Quality of Life for Thalassemic Children
}

\author{
${ }^{1}$ Donia El-Said Zaghamir, ${ }^{2}$ Rehab Hanie El-Kazaz, ${ }^{3}$ Amal Ahmed Khalil Morsy, \\ ${ }^{4}$ Momahmed Mohamed Ahmed Elmazahy
}

Assist lecturer of pediatric nursing,Faculty of Nursing, Port Said University, Assistant Professor of Pediatric Nursing Department, Faculty of Nursing, Port Said University, Professor of Pediatric nursing Faculty of Nursing, Port said University, Professor of Pediatric Medicine Faculty of Medicine Elazhar University,.

\begin{abstract}
Background: Thalassemia is the most common genetic disorder in Egypt, It is measured a fetal disease if proper chelation treatment is not established. The introduction of chelating agents able to removing extreme iron from the body has noticeably increased life expectancy time and improving the in general quality of life. the study aimed to identify the impact of an educational program about iron chelation therapy on the QoL for thalassemic children.Quasi-experimental research design was used, a convenient sample of $\mathbf{5 0}$ thalassemic children on chelation therapy, and their family caregiver at the pediatrics outpatient department at the Health Insurance Agency Hospital in Damietta city for 12 months from April 2015 to April 2016. The tools of data collection were an interview questionnaire for knowledge, and the pediatric QoL tool, child and parent versions. The results revealed that there were statistically significant improvement of children's knowledge with P-value $=0.001$. Subsequently, statistically significant improvement of children's quality of life at follow up compared with pre-intervention phase. The study recommended repetition of this research on large sample and in various places in Egypt and make the children with Thalassemia the focus of the health care team through designing several educational program and update posters and procures that improving their knowledge and then and then release improve in the quality of life of thalassemic children.
\end{abstract}

Key Words:chelation therapy,educational program, thalassemia, ,quality of life. 


\section{INTRODUCTION}

The quality of life (QOL) should be consider as an vital key of efficient treatment. As judgment of QOL differ from other form of therapeutic estimation which it causes on the person own aspect s of their comfort and evaluates another aspects of life, give a more view of comfort, latest only some studies mentioned that the health related quality of life of thalassemic children with smoothing iron overburden optimal chelation therapy decrease iron overburden complication and provide a best quality of lif (Dahlui et al., 2010).

The intensive iron chelation therapy considerably increment the lifetime and get better the QOL for Thalassemiac children. This is by dropping the amount of stored iron and preventing or reversing the toxic effect of this heavy metallic element, or accelerating the removal of the metal from the body (Brittenham et al., 2005; McCance and Grey, 2010).

So as to improve theQOL, the thalassemic children, they should know the importance of chelation therapy and gaining enough knowledge about it. As branding iron chelation therapy becomes ever more modified to the exact requirements of persons affected role , compliance to the therapy regime is intensive, particularly as iron overburden is symptomless till severe comlications emerge. uncomplicated illustration be able to assist instruct patients on iron overburden and its possible complication. such as, a serum ferritin -tacking diagram be capable of facilitate patient observe the optimistic degree outcome of chelation, e.g, a reducinging serum ferritin . organization unfavorable consequence efficiently and keep the drug schedule easy be able to too assist with compliance (Cianciulli, 2010).

The nurse can accomplish an essential part in educating thalassemic children. On chelation therapy as stress with the intention of suitable chelation therapy the children preservetheir growth, development and exist a convention living. The nurse has an chance to rally knowledge, aid to reduce stress and take into account the intervention plan for regular in chelation therapy (Zorac et al., 2013). 


\section{Significance of study:}

Thalassemia is the most common genetic disorderliness in Egypt, It is measured a fetal disease if satisfacory chelation therapy is n't established. The initiation of chelating factors able to take out extreme branding iron, it is considerably improved living (Zorac et al., 2013). New scheme for chelation, such as combination parenteral and oral chelation therapy and organ -targeted chelation, may soon have aconsiderable impact on the QOL of thalassemiac children prospect and improving the overall quality of life (Cohen et al., 2004; Naithani et al., 2005; Nathan et al., 2009). The research investigator predictable that the knowledge generated from this study will be useful for nurses, children and their concern givers and health care professional in the prevention and early detection of the disease and dealings with side effects of treatment

The study aimed To evaluate the impact of an educational program about iron chelation therapy on the quality of life (QoL) for thalassemic children.

\section{Subjects and Method:}

A quasi-experimental study was carried out at the pediatrics outpatient department at the Health Insurance Agency Hospital in Damietta city. A convenient sample consisted of 50 children having B-thalassemia major and receiving chelation therapy in the study setting, as well as their family caregivers.

\section{Tools for Data Collection}

\section{TOOL (I):Structured interview questionnaire:}

The tool include of the three parts .

Part 1: personal data sheet: This part was for collecting data about child's demographic characteristics as age, gender, birth order, level of education, as well as any school problems related to illness. It also involved questions about parents and family characteristics. 
Part 2: This covered the medical history of the child. It involved questions about the age at diagnosis, duration of illness, family history, symptoms, treatment followed including blood transfusion and desferal use details and related complications, investigations done, compliance with treatment and follow-up, as well as the problems getting medical care.

Part 3: This was intended to assess child's knowledge at various phases of the intervention. It covered three areas of knowledge as follows

- Thalassemia: 6 questions covering its nature, prevalence, causes, symptoms, complications, and causes of complications.

- Treatment: 11 questions covering types, benefits and problems of blood transfusion, iron accumulation, high iron food, food increasing iron absorption, drugs ridding body of excess iron and their benefits, use of these drugs and their side effects, and needed investigations

- Desferal: 9 questions covering its importance, weekly dose, side effects and their management such as inflammation of the abdomen, abdominal abscess, disturbed vision/ hearing, and allergy, when to stop and the symptoms that need stopping.

- Scoring: A correct answer was scored one and incorrect zero. Scores are obtained by summing the rported scores for each items. The level of Knowledge catogrized to satisfactory if the score was equal 50 percent or increased and unsatisfactory if decrease than 50 percent.

\section{TOOL (II): Pediatric Quality of Life Inventory Tool}

The Pediatric Quality of Life Inventory scales consisted of four dimensions of ( physical, emotional, social, and school functioning). Each dimension contain of two reports ( a child self-report and a parent proxy-report ) for the definite age of children. It was developed by Varni (1998) . It has a highly validity and reliability as reported by Varni et al, ( 2001) 
Scoring system: five responses from "never a problem," "almost a problem," "sometimes a problem," "often a problem," and "almost always a problem." These were scored 4,3,2,1 and 0 , respectively. The scores are obtained by summing the rported scores for each items ; a higher score indicative of greater QoL. The participants categorized accordingtheir level of QOL; to high QOL if equal 60\% or exceeded to low QOL if not exceeded than $60 \%$.

\section{Content tool Validity:}

Once the tool was prepared in their preliminary forms, it was ascertained by a jury of seven professional in nursing and medicine pediatrics. The tools were then adjusted based upon the recommendations of these experts.Changes were done according to the experts opinions.

\section{Reliability:}

Reliability of tools was done using Cronbach Alpha Test. The tools of the study were applied to 5 children. Reliability coefficient for tool I was 0.8 and for tool II was 0.7

The reliability of the QoL scale was assessed through examining its internal consistency. It showed a very good level of reliability as indicated below

\begin{tabular}{|l|l|l|}
\hline QOL scales & N of Items & Cronbach's Alpha \\
\hline Child age 8-<12 & & \\
\hline Child & 23 & 0.957 \\
\hline Parent & 23 & 0.954 \\
\hline Child age 12-18 & & \\
\hline Child & 23 & 0.966 \\
\hline Parent & 23 & 0.967 \\
\hline
\end{tabular}

\section{Method of Study}

- The General manager of the National Health Insurance hospital was informed by formal letter from the Faculty of Nursing in Port Said.

- Informed consent was obtained from each child and their caregivers in the study . the researcher then cleared the aim of the study. each child and their caregivers was assured that the information obtained was Confidential . 
- A pilot study was implement after review of data collection tool by seven experts. It was applied on five child and their caregivers with thalassemia attending the National Health Insurance hospital.The aims of the pilot study were to assess the applicability and clarify of the data collection tools.

- The study was administered through four phases.

- Assessment Phase (Pretest): it involved preparation of the tools and assessment of the children's knowledge related to thalassemia and chelation therapy, in addition to assessment of their QoL, both children and their parents' views before the intervention. The researcher visited the study settings, met with the eligible children and their parents, clarified to them the reasearch purpose. After obtaining parent caregiver's consent and child assent, the researcher started the interview using the first tool. This was conducted individually and privately in the study setting according to hospital policy. Then, the QoL questionnaire was filled by interviewing the children and parents. It took approximately 35 to 40 minutes to fulfill the interview. The data collected constituted a pretest for baseline comparisons. It also served in preparing the educational program based on identified needs.

Planning Phase: The researcher started to develop the steps of program based on the pretest phase. It was written in simple Arabic language. The program general aim was to improve children's information, practice and their QoL. The program included educational materials to improve knowledge regarding the definition of thalassemia, its types, clinical manifestations, predisposing factors, investigations, and treatment. It also covered instructions concerning the chelation and its effect on the QoL of children. The program also addressed knowledge areas related to prevention and screening of thalassemia. An illustrated Arabic-language booklet was prepared by the researcher in simple terms to be distributed to attendants by the end of the program

Implementation phase: The program was administered in five sessions; the duration of each session lasting from 45 to 60 minutes. The sample of children and their caregivers was divided into 10 groups, each including five members. At the beginning of the first session of the program, the attendants were oriented about the program objectives, contents, and procedures. The program was implemented two days per week during a period of 6 months from November 2015 to April 2016. 
Evaluation Phase:The effectiveness of the program was based on assessing the improvement in children's knowledge and QoL. This was achieved through comparing the pretest with posttest immediately done after the implementation of the program, and the follow-up test carried out three months later.

Statistical analysis of data was performed using statistical software package (SPSS 20.0). Qualitative categorical variables were compared using chi-square test. Whenever the expected values in one or more of the cells in a $2 \times 2$ tables was less than 5, Fisher exact test was used instead. Spearman rank correlation was used for assessment of the inter-lationships among quantitative variables and ranked one. Multiple linear regression analysis was used and analysis of variance for the full regression models done. Statistical significance was considered at $\mathrm{p}$-value $<0.05$.

\section{RESULTS:}

Table( 1) :The study sample consisted of 50 children whose age ranged between 8 and 18 years, median 12.0 years, with slightly more females $(56.0 \%)$ as shown in Table 1. The majority were firstborn children (82.0\%). Approximately one-third of the children left school (32.0\%), mostly at the primary level. Among those who continued in school, more than half were at the primary level of education (55.9\%). Overall, more than threefourth of the children were able to read and write $(76.0 \%)$.

Table (2): regarding parents, this table clarfies that mother's age range among 27 to50 years, medium 35.5 years, while fathers' age ranged between 33 and 55 years, median 41.0 years. Most mothers and fathers had basic/intermediate level of education $50.0 \%$ and $60.0 \%$ respectively. The majority of the mothers were housewives $(86.0 \%)$ and of the fathers were employees $(82.0 \%)$,

Table (3): demonstrates that the area of lowest percentage of satisfactory knowledge between the studied children prior to the program was that of management $(12.0 \%)$. Statistically significant improvements were revealed at the post-intervention phase in all areas of knowledge $(\mathrm{p}<0.001)$. in the follow-up, nearby was slight decrease, especially into the area of management (54.0\%). However, the percentages of satisfactory knowledge remained significantly higher compared to pretest. 
Concerning the QoL of the studied children, Table 4 indicates generally low levels before the intervention. This was most evident regarding the emotional and scholar dimensions from both child and parent viewpoints. Slight non-statistically significant improvements were noticed at the post-implementation. while, statistical significant were found in the follow-up from both child and parent views in all QoL domains. The only exception was the social domain from parents' viewpoint, which improved but with no statistically significant difference..

Table (5): As illustrated in Table 5, no statistical significant relations revealed among children' knowledge and their QoL from own or parents' view at the pre and postintervention phases. Also, statistically significant associations in the follow-up phase for both child $(\mathrm{p}=0.002)$ and parent $(\mathrm{p}=0.004)$ views. As the table demonstrates, the percentages of children with high QoL were higher among those having satisfactory knowledge.

Table (6): demonstrates a statistical significant high positive correlation between the score of QoL from child \& parent views $(r=0.782)$. The scores of knowledge had statistically significant moderate positive correlations with both QoL scores 
Table 1: personal data of children in study sample $(n=50)$

\begin{tabular}{|l|c|c|}
\hline & Frequency & Percent \\
\hline Child age: & \multicolumn{2}{|c|}{} \\
$<12$ & 26 & 52.0 \\
$12+$ & 24 & 48.0 \\
Range & \multicolumn{2}{|c|}{$8.0-18.0$} \\
Mean \pm SD & \multicolumn{2}{|c|}{$12.6 \pm 3.0$} \\
Median & \multicolumn{2}{|c|}{12.0} \\
\hline sex: & 22 & 44.0 \\
Male & 28 & 56.0 \\
Female & \multicolumn{2}{|c}{} \\
\hline Birthorder: & 41 & 82.0 \\
1 & 9 & 18.0 \\
2+ & \multicolumn{2}{|c|}{} \\
\hline Education: & 16 & 32.0 \\
Left school & 34 & 68.0 \\
Studying & \multicolumn{2}{|c|}{} \\
Left at level: & 14 & 87.5 \\
$\quad$ Primary & 1 & 6.3 \\
$\quad$ Preparatory & 1 & 6.3 \\
$\quad$ Secondary & \multicolumn{2}{|c|}{} \\
$\quad$ Primary & 19 & 55.9 \\
$\quad$ Preparatory & 6 & 17.5 \\
\hline
\end{tabular}


Table 2: Percent distribution of studied parents related to Socio-demographic characteristics.

\begin{tabular}{|c|c|c|}
\hline & Frequency & Percent \\
\hline $\begin{array}{l}\text { Mother age: } \\
<35 \\
35+ \\
\text { Range } \\
\text { Mean } \pm \text { SD } \\
\text { Median } \\
\end{array}$ & $\begin{array}{c}27.0-50.0 \\
36.0 \pm 5.1 \\
35.5 \\
\end{array}$ & $\begin{array}{r}38.0 \\
62.0 \\
0.0 \\
5.1 \\
\end{array}$ \\
\hline $\begin{array}{l}\text { Mother education: } \\
\text { Illiterate/ Read/write } \\
\text { Basic/Intermediate } \\
\text { University }\end{array}$ & $\begin{array}{l}14 \\
25 \\
11 \\
\end{array}$ & $\begin{array}{l}28.0 \\
50.0 \\
22.0\end{array}$ \\
\hline $\begin{array}{l}\text { Mother job status: } \\
\text { Housewife } \\
\text { Working } \\
\end{array}$ & $\begin{array}{c}43 \\
7\end{array}$ & $\begin{array}{l}86.0 \\
14.0\end{array}$ \\
\hline $\begin{array}{l}\text { Father age: } \\
<40 \\
40+ \\
\text { Range } \\
\text { Mean } \pm \text { SD } \\
\text { Median }\end{array}$ & \multicolumn{2}{|c|}{$\begin{array}{c}33.0-55.0 \\
41.8 \pm 5.8 \\
41.0 \\
\end{array}$} \\
\hline $\begin{array}{l}\text { Father education: } \\
\text { Illiterate/ Read/write } \\
\text { Basic/Intermediate } \\
\text { University }\end{array}$ & $\begin{array}{c}13 \\
30 \\
7 \\
\end{array}$ & $\begin{array}{l}26.0 \\
60.0 \\
14.0 \\
\end{array}$ \\
\hline $\begin{array}{l}\text { Father job: } \\
\text { Employee } \\
\text { Worker }\end{array}$ & $\begin{array}{c}9 \\
41\end{array}$ & $\begin{array}{l}18.0 \\
82.0\end{array}$ \\
\hline
\end{tabular}

Table 3: Total knowledge among children throughout the intervention.

\begin{tabular}{|c|c|c|c|c|c|c|c|c|}
\hline \multirow{3}{*}{$\begin{array}{c}\text { Satisfactory } \\
\text { KnowledgeAbout }\end{array}$} & \multicolumn{6}{|c|}{ Time } & \multirow{3}{*}{$\begin{array}{c}X^{2} \\
(p-v a l u e) \\
\text { Pre-post }\end{array}$} & \multirow{3}{*}{$\begin{array}{c}X^{2} \\
(p-v a l u e) \\
\text { Pre-FU }\end{array}$} \\
\hline & \multicolumn{2}{|c|}{ Pre } & \multicolumn{2}{|c|}{ Post } & \multicolumn{2}{|c|}{$F \boldsymbol{F}$} & & \\
\hline & No. & $\%$ & No. & $\%$ & No. & $\%$ & & \\
\hline Thalassemia & 13 & 26.0 & 47 & 94.0 & 39 & 78.0 & $\begin{array}{c}48.17 \\
(<0.001 *)\end{array}$ & $\begin{array}{c}27.08 \\
(<0.001 *)\end{array}$ \\
\hline Management & 6 & 12.0 & 43 & 86.0 & 27 & 54.0 & $\begin{array}{c}54.78 \\
(<0.001 *)\end{array}$ & $\begin{array}{c}19.95 \\
(<0.001 *)\end{array}$ \\
\hline Desferal & 13 & 26.0 & 47 & 94.0 & 42 & 84.0 & $\begin{array}{c}48.17 \\
(<0.001 *)\end{array}$ & $\begin{array}{c}33.98 \\
(<0.001 *)\end{array}$ \\
\hline
\end{tabular}


Table 4 : Quality of life (QoL) as viewed by children and their parents throughout the intervention.

\begin{tabular}{|c|c|c|c|c|c|c|c|c|}
\hline \multirow{3}{*}{$\begin{array}{l}\text { High } \\
\text { QoL }\end{array}$} & \multicolumn{6}{|c|}{ Time } & \multirow{3}{*}{$\begin{array}{c}X^{2} \\
(p-v a l u e) \\
\text { Pre-post }\end{array}$} & \multirow{3}{*}{$\begin{array}{c}X^{2} \\
(p-v a l u e) \\
\text { Pre-FU }\end{array}$} \\
\hline & \multicolumn{2}{|l|}{ Pre } & \multicolumn{2}{|c|}{ Post } & \multicolumn{2}{|l|}{$F U$} & & \\
\hline & No. & $\%$ & No. & $\%$ & No. & $\%$ & & \\
\hline CHILD VIEW: & & & & & & & & \\
\hline Physical & 17 & 34.0 & 21 & 42.0 & 43 & 86.0 & $\begin{array}{c}0.68 \\
(0.41)\end{array}$ & $\begin{array}{c}28.17 \\
(<0.001 *)\end{array}$ \\
\hline Emotional & 7 & 14.0 & 12 & 24.0 & 37 & 74.0 & $\begin{array}{c}1.62 \\
(0.20)\end{array}$ & $\begin{array}{c}36.53 \\
(<0.001 *)\end{array}$ \\
\hline Social & 32 & 64.0 & 34 & 68.0 & 41 & 82.0 & $\begin{array}{c}0.18 \\
(0.67)\end{array}$ & $\begin{array}{c}4.11 \\
(0.04 *)\end{array}$ \\
\hline Scholar & 5 & 10.0 & 9 & 18.0 & 26 & 52.0 & $\begin{array}{c}1.33 \\
(0.25)\end{array}$ & $\begin{array}{c}20.62 \\
(<0.001 *)\end{array}$ \\
\hline $\begin{array}{l}\text { PARENT } \\
\text { VIEW: }\end{array}$ & & & & & & & & \\
\hline Physical & 14 & 28.0 & 18 & 36.0 & 37 & 74.0 & $\begin{array}{c}0.74 \\
(0.39)\end{array}$ & $\begin{array}{c}21.17 \\
\left(<0.001^{*}\right)\end{array}$ \\
\hline Emotional & 4 & 8.0 & 9 & 18.0 & 23 & 46.0 & $\begin{array}{c}2.21 \\
(0.14)\end{array}$ & $\begin{array}{c}18.32 \\
(<0.001 *)\end{array}$ \\
\hline Social & 31 & 62.0 & 32 & 64.0 & 38 & 76.0 & $\begin{array}{c}0.04 \\
(0.84)\end{array}$ & $\begin{array}{l}2.29 \\
(0.13)\end{array}$ \\
\hline Scholar & 3 & 6.0 & 7 & 14.0 & 28 & 56.0 & $\begin{array}{c}1.78 \\
(0.18)\end{array}$ & $\begin{array}{c}29.22 \\
(<0.001 *)\end{array}$ \\
\hline
\end{tabular}

Table 5: Relations among knowledge \& QoL throughout the intervention

\begin{tabular}{|c|c|c|c|c|c|c|}
\hline & \multicolumn{4}{|c|}{ Knowledge } & \multirow{3}{*}{$X^{2}$ test } & \multirow{3}{*}{ p-value } \\
\hline & \multicolumn{2}{|c|}{ Satisfactory } & \multicolumn{2}{|c|}{ Unsatisfactory } & & \\
\hline & No. & $\%$ & No. & $\%$ & & \\
\hline \multicolumn{7}{|l|}{ PRE: } \\
\hline High & 3 & 27.3 & 8 & 72.7 & & \\
\hline Low & 7 & 17.9 & 32 & 82.1 & Fisher & 0.67 \\
\hline $\begin{array}{l}\text { Parent view: } \\
\text { High }\end{array}$ & 2 & 40.0 & 3 & 60.0 & & \\
\hline Low & 8 & 17.8 & 37 & 82.2 & Fisher & 0.26 \\
\hline \multicolumn{7}{|l|}{ POST: } \\
\hline $\begin{array}{l}\text { Child view: } \\
\text { High }\end{array}$ & 18 & 1000 & 0 & 00 & & \\
\hline Low & 28 & 87.5 & 4 & 12.5 & Fisher & 0.28 \\
\hline \multicolumn{7}{|l|}{ Parent view: } \\
\hline High & 11 & 100.0 & 0 & 0.0 & & \\
\hline Low & 35 & 89.7 & 4 & 10.3 & Fisher & 0.56 \\
\hline \multicolumn{7}{|l|}{ FU: } \\
\hline \multicolumn{7}{|l|}{ Child view: } \\
\hline High & 33 & 94.3 & 2 & 5.7 & & \\
\hline Low & 8 & 53.3 & 7 & 46.7 & Fisher & $0.002 *$ \\
\hline \multicolumn{7}{|l|}{ Parent view: } \\
\hline High & 31 & 93.9 & 2 & 6.1 & & \\
\hline Low & 10 & 58.8 & 7 & 41.2 & Fisher & $0.004^{*}$ \\
\hline
\end{tabular}


Table 6: Correlation matrix of knowledge \& QoL scale domains scores

\begin{tabular}{|l|c|l|l|}
\hline \multirow{2}{*}{} & \multicolumn{3}{|c|}{ Spearman's rank correlation coefficient } \\
\cline { 2 - 4 } & Knowledge & QoL (child) & QoL (parent) \\
\hline Knowledge & & & \\
\hline QoL (child) & $.490 * *$ & & \\
\hline QoL (parent) & $.390^{* *}$ & $.782 * *$ & \\
\hline
\end{tabular}

\section{DISCUSSION:}

Chelation therapy education is vital for thalassemic children and most favorable of its can diminish iron overburden complaint, and supply improvement QoL (Dahlui et al., 2010).

The execution for present study implementation assist to important better in all areas of knowledge regarding of disease itself, its management, and the use of desferal. Thus, by the end of the educational program, almost all participant had satisfactory totality knowledge. This indicates that the program was effectual in achieving its objective concerning knowledge improvement. The success of the program is certainly attributed to its subject matter, which was based on identified unmet needs, as well as its procedures that followed the rule of participatory adult learning

In agreement with the present study findings concerning the positive impact of the educational program on participants' knowledge regarding thalassemia, previous studies reported similar successes. Thus, Abu Samra et al (2015) a study conducted in Egypt demonstrated significant improvement in the knowledge of thalassemic children following an educational intervention. Moreover, Hassan (2010) who conducted a study to evaluate the impact of health educational program on adherence of thalassemic children in Cairo, Egypt, found significant improvement in their related knowledge after implementation of the educational program.

One of the main objectives of the present study was to improve the QoL of thalassemic children through improving knowledge. The study findings revealed generally low QoL of children before the intervention. This was particularly evident in the emotional 
and scholar dimensions. In fact, approximately one-third of these children left school, mostly at the primary level. Moreover, the majority had school problems due to their illness, and needed special health care at school. This would certainly have a negative impact on their emotional QoL. Added to this is the over-protective attitudes from the family, which would lead to quitting school because of the long distance between home and school. Moreover, many parents feel guilty for their child's inherited illness; and this may make them less disciplinary with their child about studying

In agreement with the foregoing, Adam et al (2017) in Egypt and in Sharma et al (2017) in India reported low QoL scores among thalassemic children. Moreover, $\boldsymbol{A l}$ Mosooi (2011) highlighted that thalassemia leads to school absenteeism of a large number of the affected children, and limited the activities of one third of them. On the same line, Caocci et al. (2012) affirmed that thalassemia major causes considerable disturbance in learning and societal behavior. The affected children frequently abscent of school for the reason that of hospital admission to take usual monthly blood transfusion and/or management of complication. Additionally, studies demonstrated low Qol among thalassemic children because of the outcome of the thalassemia and its compliaction of treatment (Ismail et al., 2006; Shaligram et al., 2007).

According to the current study results, the QoL of thalassemic children needed some time to demonstrate significant improvements. Thus, the highly statistical significant only noticed in the follow-up phase. It's quite plausible since the change in knowledge can be effected immediately after training, whereas the change in QoL, being based on other variables such as the physical and psychological health status, the disease-related factors such as symptoms and signs, as well as treatment side effects. Nonetheless, the results show the effectiveness of the educational program in children's QoL through improving their compliance, and achieving better ferritin levels. This was established by multivariate analysis, which recognized the study implementation program as a main positive interpreter of the QoL scores, from both child and parent views. This may be explained by the better ability of children understand and deal with their illness, and how to live with it.

The foregoing present study findings are in congruence by Rafii et al (2016) in Iran demonstrated significant improvements in the QoL of thalassemic patients following 
an educational program. A similar achiever was also reported in a study in Egypt ( $\boldsymbol{A} \boldsymbol{b} \boldsymbol{u}$ Samra et al, 2015). Moreover, Dahlui et al. (2009) discovery that transfusion dependent thalassemic children on optimum chelation therapy had higher QoL scores. This was attributed to that best chelation therapy might lesser the level of serum ferritin, it is associated with a decrease level of iron overburden complication and improve QoL. Furthermore, a study in Iraq revealed that the adolescents who complied with chelation therapy had better QoL (Abdul-Zahra et al, 2016).

In the current study, the scores of knowledge had statistically significant moderate positive correlations with both QoL scores. This indicates the importance of improving the knowledge of thalassemic children and their parents due to its positive impact on children's QoL. In line with this, Al-Mosooi (2011) found a significant association between disease information among thalassemic children and all their QoL domains

Derived from the results of the current study, it was concluded that knowledge of thalassemic children about the disease is low, with associated low Quality of Life (QoL). The accomplishment of the program is successful in increasing their knowledge of the various aspects of the disease and its management and Meanwhile, the improvement in their QoL is only evident at the follow-up phase, indicating that it needs longer time to be achieved compared with knowledge.

The study recommended that, Health teaching and counseling programs should be provided for thalassemic children and their caregivers with to decrease burden on them through updated posters and brochures that help improve their knowledge and then releases

\section{REFERENCES:}

Abdul-Zahra H.A., Hassan M.K., and Ahmed B.A. (2016): Health-related Quality of Life in Children and Adolescents With $\beta$-Thalassemia Major on Different Iron Chelators in Basra, Iraq. J PediatrHematol Oncol.;38(7):503-11. doi: 10.1097/MPH. 0000000000000663

Abu Samra O., Auda W., Kamhawy H., and Al-Tonbary Y. (2015): Impact of educational programme regarding chelation therapy on the quality of life for B- 
thalassemia major children. Hematology.;20(5):297-303. doi: 10.1179/1607845414Y. 0000000197. Epub 2014 Sep 2.

Adam S., Afifi H., Thomas M., Magdy P., and El-Kamah G. (2017): Quality of Life Outcomes in a Pediatric Thalassemia Population in Egypt. Hemoglobin.;41(1):16-20. doi: 10.1080/03630269.2017.1312434. Epub 2017 Apr 25

Al-Mosooi K.M. (2011): Assessment of health quality of life upon school age children (6-12) with Thalassemia at Thalassemia center in Ibn - Baladi Hospital Thi-Qar Medical Journal (TQMJ); 5 (2): 100 - 108.

Brittenham G.M., Nathan D.G., Olivieri N.F., Pippard M.J., and Weatherall D.J. (2005): Deferiprone versus desferrioxamine in thalassemia and validation \& utility. Lancet; 11:361:183-84.

Cianciulli P. (2010): Iron Chelation Therapy in thalassemia syndrome s. Mediterranean Journal of hematology and infectious disease;1(1). Available at http://www.mjhid. org/article/view/529/html 12 .Accessed at April 13, 2013

Dahlui M., Hishamshah M. and Rahman J. (2010): Quality of life in transfusion dependant thalassemia patients on desferrioxamine treatment 50 (8): 794-799.

Hassan E.A. (2010): Impact of educational program on adherence of thalassemia children with iron chelation therapy in hematology clinics. Published Doctoral Dissertation, Faculty of Nursing, Cairo University, Cairo

Ismail A., Cambell M.J., Ibrhaim H.M., and Jones G. (2006): Health related quality of life in Malaysian children with Thalassemia health and quality of life outcomes J. Adolesc.; 27: 213 - 216. JAMA; 277: 1787 - 1793.

McCance K. and Grey T. (2010): Altered cellular and tissue biology, 6th ed., Mosby com; P. 952

Rafii Z., Ahmadi F., Nourbakhsh S.M., and Hajizadeh E. (2016): The Effects of an Orientation Program on Quality of Life of Patients with Thalassemia: a QuasiExperimental Study. J Caring Sci.;5(3):223-229. eCollection 2016 Sep. 
Shaligram D., Girimajis and Chaturved S.K. (2007): Psychological problems and quality of life in children with Thalassemia Indian. Journal of Pediatrics; 74(8): 727 730. .

Sharma S., Seth B., Jawade P., Ingale M., and Setia M.S. (2017): Quality of Life in Children with Thalassemia and their Caregivers in India. Indian J Pediatr.;84(3):188194. doi: 10.1007/s12098-016-2267-z. Epub 2016 Dec 7

Varni J.W., Seid M., and Kurtin P.S. (2001): reliability and validity of the Pediatric Quality of Life Inventory version 4.0 generic core scales in healthy and patient populations. Med Care; 39 (8): 800-12

Zorac J., Alpern E., Brown L., Loomes K., Marino B., Mollen C., and Raffini J. (2013): Clinical handbook of pediatrics, 5th ed., Philadelphia: Lippincott Williams and Wilkins; p. 431 
تأثير برنامج تعليمي عن العلاج بازالة الحديد على جودة الحياة للاطفال المرضى بأنيميا

\section{البحر الأبيض المتوسط}

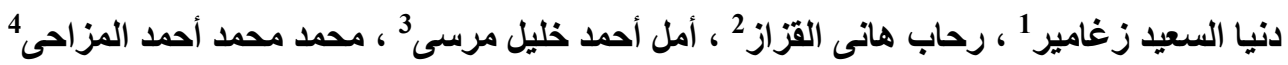

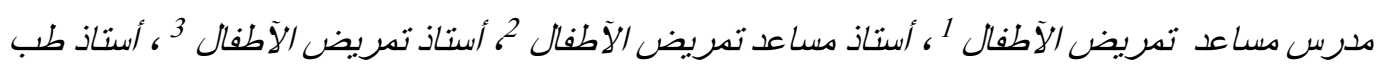
4 الوطفال

\section{الـخـلاصــة}

تهدف هذه الدراسة شبه التجريبية إلي تقييم تأثير برنامج تعليمي عن العلاج بإز الة الحديد على جودة الحياة

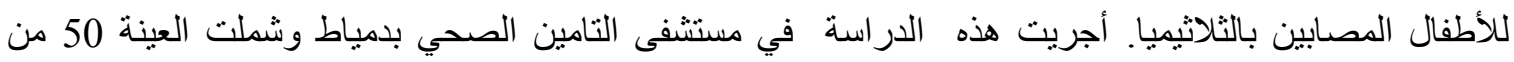

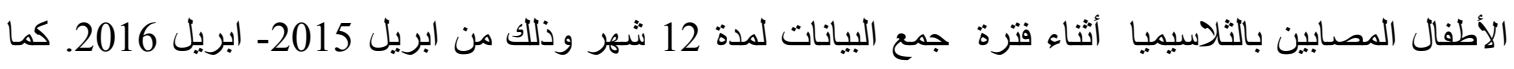

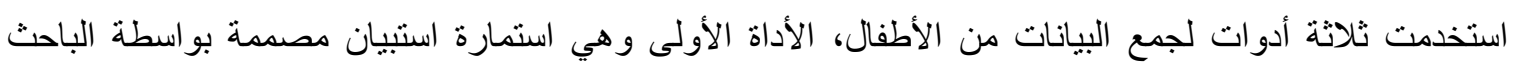

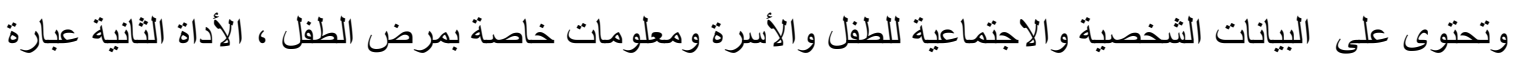

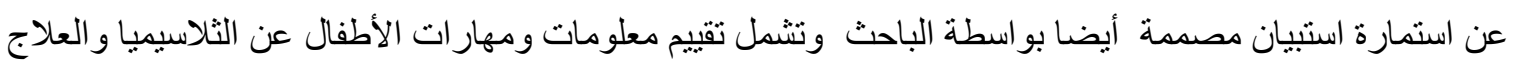

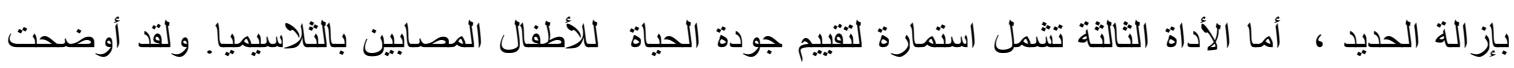

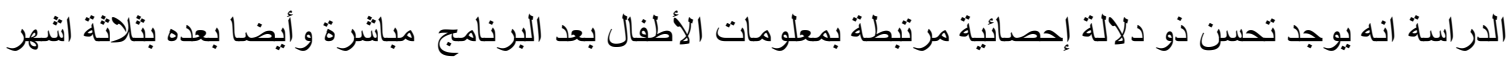

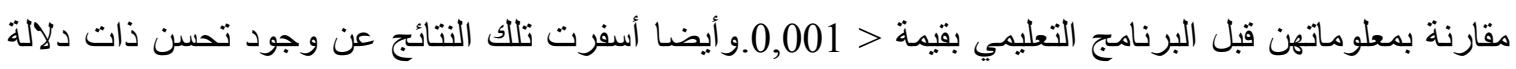

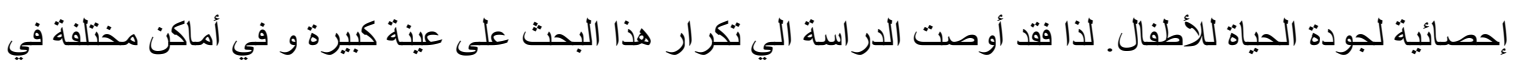
مصر وجعل أمهات الأطفال المصابين بالثلاسيميا محور اهتمام فريق الرعاية الصحية من خلال النشرات الهات المحدثة و الملصقات و الكتيبات التي تساعد علي تحسين معلوماتهن ومن ثم تحسين الحالة الصحية لأطفالهن

الكلمات المرشدة : برنامج تعليمي- معلومات ومهارات الأطفال - الثنلاسيميا_العلاج باز الة الحديد-جودة الحياة 